\title{
Building Communities of Peace: Arendtian Realism and Peacebuilding
}

This is a post-peer-review, pre-copyedit version of an article published in Polity.

Please do not quote from this version.

The final authenticated version is available online at:

https://www.journals.uchicago.edu/doi/10.1086/711647.

\author{
Shinkyu Lee \\ sk.james.lee@gmail.com
}

\begin{abstract}
Recent studies of peacebuilding highlight the importance of attending to people's local experiences of conflict and cooperation. This trend, however, raises the fundamental questions of how the local is and should be constituted and what the relationship is between institutions and individual actors of peace at the local level of politics. I turn to Hannah Arendt's thoughts to address these issues. Arendt's thinking provides a distinctive form of realism that calls for stable institutions but never depletes the spirit of resistance. Peacebuilding guided by this insight seeks to enable parties in conflict to voice their competing opinions by acting agonistically in public and to help them align their disruptive yet creative voices with a desire to establish and sustain common institutions. Thus, Arendt's thinking not only offers a way to increase sensitivity to local differences but also to provide direction to the politics of resistance. In the end, it offers a balanced insight into peacebuilding and local agency beyond the contemporary liberal and critical approaches to peace.
\end{abstract}

\section{Keywords}

Hannah Arendt, worldliness, realism, peacebuilding, the local, resistance

\section{Acknowledgements}

I am grateful to my erstwhile dissertation committee, Dana Villa, Catherine Zuckert, Ernesto Verdeja, and Fred Dallmayr, for their critiques and encouragements regarding the basic ideas on Arendt's thinking displayed in this paper. The article has also benefited from constructive comments and suggestions by Leonard Feldman and four anonymous reviewers for Polity as well as the participants of the Realism panel at the 2016 meeting of the American Political Science Association, especially the discussants Thomas Donahue and Ryan Phillips. Finally, I would like to thank David Cortright, Rafael Khachaturian, and Vince Bagnulo for their informal and friendly exchanges of views on pacifism, realism, and democratic agency. 
A major topic of concern for the extant peacebuilding scholarship is intervention in the form of "external" efforts to achieve long-lasting peace in conflict zones. How to empower local ownership of peace has emerged as a hotly debated issue because, for successful peace settlements, actual parties of conflict need to be convinced of the legitimacy and efficacy of intervention. ${ }^{1}$ However, the current debate in peacebuilding also raises some other fundamental issues: What is the nature of the local? What types of local communities are beneficial for eradicating sources of violence and fostering sustainable peace? How should the local be constituted to achieve these goals? In fact, these questions are not separable from and are even foundational to the goal of enhancing local agency for peacebuilding, for unless we are clear about normative parameters for the constitution of the local or the relationship between institutions and individual actors of peace at the local level of politics, peace engagements will be haphazard and arbitrary.

Neither liberal nor critical peace approaches have successfully addressed these questions about the local. The proponents of liberal peace place a strong emphasis on democracy and human rights as well as on globalized markets and neoliberal development. ${ }^{2}$ By doing so, they conceive of the local as a device, if not an obstacle, that gains relevance only

${ }^{1}$ Michael Doyle and Nicholas Sambanis, Making W ar and Building Peace: United Nations Peace Operations (Princeton: Princeton University Press, 2006), 63-68; John Paul Lederach and R. Scott Appleby, "Strategic Peacebuilding: An Overview," in Strategies of Peace: Transforming Conflict in a Violent World, ed. Daniel Philpott and Gerard Powers (Oxford: Oxford University Press, 2010), 19-44; Roger Mac Ginty and Oliver Richmond, "The Local Turn in Peace Building: A Critical Agenda for Peace," Third World Quarterly 34 (2013): 763-83; and Louise Wiuff Moe and Finn Stepputat, "Peacebuilding in an Era of Pragmatism," International Affairs 94 (2018): 293-99.

${ }^{2}$ Michael Mandelbaum, The Ideas that Conquered the World: Peace, Democracy, and Free Markets in the Twenty-First Century (New York: Public Affairs, 2002); United Nations, "An Agenda for Peace-Preventive Diplomacy, Peacemaking, and Peacekeeping: Report of the SecretaryGeneral," A/47/277 (June 17, 1992), at https://digitallibrary.un.org/record/1473582?ln=en; and G. John Ikenberry, "The End of Liberal International Order?” International Affairs 94 (2018): 7-23. 
when it serves to put liberal values into practice. This occurs because their strong convictions about moral, institutional criteria have the effect of obviating serious endeavors to engage with the local. Alternatively, critical peace scholars seek to increase sensitivity to local actors and forms of agency that are unique to each setting. ${ }^{3}$ This approach, however, increases the danger of presenting the local in a complete or confined form. ${ }^{4}$ Even the new trend of critical peace scholarship that attends to constant identity blurring in the politics of everyday life is not uncontroversial, as it renders any peace intervention virtually exclusionary and futile while also underrating challenges that would emerge when the local remains solely a site of contestation. ${ }^{5}$

This article explores a theoretical ground for providing balanced insight into peacebuilding that helps us conceive of the local neither as a completely regulated space nor as a site of sheer indeterminacy. For this purpose, I turn to Hannah Arendt's political thoughts. Her thinking shows a distinctive way of engaging in the real world of politics, a political stance that appreciates the endeavor to establish common institutions for peace settlements and yet maintains the spirit of agonism by actively promoting new opinions and insights and integrating them into existing relationships. I argue that such a distinctive "realist" orientation toward politics cultivates stable institutions that would never deplete the agonistic spirit of

\footnotetext{
${ }^{3}$ Oliver Richmond and Audra Mitchell, "Peacebuilding and Critical Forms of Agency: From Resistance to Subsistence," Alternatives: Global, Local, Political 36 (2011): 326-44, at 326; Mac Ginty and Richmond, "The Local Turn," 765; and Roger Mac Ginty, "Where Is the Local? Critical Localism and Peacebuilding," Third World Quarterly 36 (2015): 840-56, at 848.

${ }^{4}$ Roland Paris, “Saving Liberal Peacebuilding," Review of International Studies 36 (2010): 33765 , at 340 .

${ }^{5}$ Roger Mac Ginty, "Hybrid Peace: How Does Hybrid Peace Come About?" in A Liberal Peace? The Problems and Practices of Peacebuilding, ed. Susanna Campbell, David Chandler, and Meera Sabaratnam (London: Zed Books, 2011), 209-25; Julian Graef, Practicing Post-Liberal Peacebuilding: Legal Empowerment and Emergent Hybridity in Liberia (New York: Palgrave, 2015); and Annika Björkdahl and Kristine Höglund, "Precarious Peacebuilding: Friction in GlobalLocal Encounters,” Peacebuilding 1 (2013): 289-99.
} 
resistance, thereby eschewing two dangers to peace: a strong projection of comprehensive criteria onto peace processes, and skepticism about establishing common institutions for peace. From this perspective, we gain a sophisticated view of peacebuilding and local agency: peacebuilding should seek to enable parties in conflict to voice their competing opinions by acting agonistically in public and help them align their disruptive yet creative voices with a desire to establish and sustain common institutions facilitating debate and mutual deliberation.

Although this article explores a form of Arendtian peace, I do not limit the analysis to Arendt's specific references to peace. Instead, I focus on investigating the relevance of her theory of free politics, represented via a distinctive form of realism, for contemporary peacebuilding. We should acknowledge that Arendt herself never elaborated a comprehensive theory of peace. Her few accounts of peace only appear when she engages with other topics, such as freedom or violence. ${ }^{6}$ Such caution closely relates to her concern about the conventional idea of peace defined as a mere absence of violence. Her problem with this narrow view of peace is evident when she criticizes Zionist leaders for their quest to create an isolated haven for Jews, forever safe from anti-Semitism. ${ }^{7}$ Feasible or not, Arendt thinks constructing such an organic national body in Palestine would only, and temporarily, achieve the absence of violence. Because a "negative" conception of peace-equating it with

\footnotetext{
${ }^{6}$ Hannah Arendt, On Revolution (New York: Penguin Books, 2006), 202; On Violence (New York: Harcourt, 1970), 51; and "Introduction into Politics," in The Promise of Politics, ed. Jerome Kohn (New York: Schocken Books, 2005), 93-200, at 199.

${ }^{7}$ Hannah Arendt, “The Jewish State: Fifty Years After, Where Have Herzl's Politics Led?” in The Jewish Writings, ed. Jerome Kohn and Ron Feldman (New York: Schocken Books, 2007), 375-87, at 385; and "Peace or Armistice in the Near East?" in The Jewish Writings, 423-50, at 425.
} 
armistice—was still prevalent in her time, ${ }^{8}$ Arendt had good reasons to prefer using terms other than peace in articulating her political thoughts.

Yet the limitations of negative peace as a discourse of peacebuilding have been widely acknowledged in contemporary peace studies. Today, no peace scholars think the mere absence of violence is all that peace engagements can achieve and should aim at. Hence the gap between Arendt's disapproving view of (negative) peace and peace scholarship has narrowed. Of course, owing to her strong interest in agonistic politics, her thinking differs from pacifism. ${ }^{9}$ But a positive appraisal of war, such as Hegel notably made, as an instrument to preserve "the ethical health of nations," has no place in Arendt's free politics. ${ }^{10}$ Quite the contrary, Arendt challenges the conventional conception of politics as inherently violent. Her fundamental interest lies in articulating a form of contentious politics that does not develop into violence and domination but creates new relationships and common institutions. This attitude toward politics, which I will name "worldly realism," has important implications for how to constitute the local for sustainable peace.

The article is divided into two parts. I first identify a source of realism in Arendt's thoughts through a novel reading of her famous accounts of the vita activa and worldliness.

\footnotetext{
${ }^{8}$ For two conceptions (negative and positive) of peace, see Johan Galtung's seminal essay, "Violence, Peace, and Peace Research," Journal of Peace Research 6 (1969): 167-91, at 183.

${ }^{9}$ This is particularly the case when we define pacifism as the ideological assertion that violence should be rejected in political and personal life. On the difference between pacifism and nonviolence, see Dustin Ells Howes, "The Failure of Pacifism and the Success of Nonviolence," Perspectives on Politics 11 (2013): 427-46. For an illuminating attempt to formulate a "political" version of pacifism between the ideological and pragmatic approaches to pacifism, see Kimberly Hutchings, "Pacifism Is Dirty: Towards an Ethico-Political Defense," Critical Studies on Security 6 (2018): 176-92.

${ }^{10}$ G.W.F. Hegel, Elements of the Philosophy of Right (Cambridge: Cambridge University Press, 1991), 361. For Hegel's varied views on war as it relates to the different levels of politics, see Shinkyu Lee, "Freedom, the State, and War: Hegel's Challenge to World Peace," International Politics 54 (2017): 203-20, at 209-14.
} 
After specifying a vision of peace that Arendt's realism fosters, I conclude by exploring the implications of this aspect of her thinking for contemporary peacebuilding.

\section{Arendtian Realism}

The aim of this section is to articulate the basic features of Arendt's thinking relevant to the discussion of peacebuilding. I begin with her emphasis on the politics of action as opposed to the violence the human activity of work entails. I then complicate the strict dichotomy between action and work by pointing out Arendt's appreciation of work's stability-generating feature. I argue that what informs Arendt's ambiguous accounts of work is her recognition of the need to balance agonistic action and institutional stability for maintaining public worlds. This analysis is a preliminary step for the later examination of the shortcomings of both liberal and critical peacebuilding in their efforts to constitute political communities for peace.

\section{The Advantages of Action}

Arendt's thinking shows that violence occurs as one imposes one's end or will onto others. In her view, if we put action into practice as a central mode of politics, violence will disappear, and free politics in the form of non-domination will emerge. The following explicates the advantages Arendt's action-driven politics has over the conventional view of politics where violence is unavoidable through constant struggles for power and domination.

To Arendt, the fundamental purpose of politics is to achieve freedom, and free politics is only possible when diverse equals appear in a common space and exchange their different opinions. However, consistent prejudice against free politics exists in the Western tradition of political thought. This tradition takes "the distinction between ruling and being ruled [or] 
between rulers and subjects" as "the essence of all political organization." 11 A disastrous result of such thinking is the substitution of making for acting. ${ }^{12}$ Arendt's articulation of vita activa (human activities) shows the dangers this kind of confusion entails. According to Arendt, three human activities make up the vita activa: labor, work, and action. Labor is the activity that produces the necessary resources for maintaining the life processes of human beings. By contrast, work is the unnatural activity that makes things, ranging from tools to art. Because "the process of making is itself entirely determined by the categories of means and end," 13 work is the defining characteristic of homo faber (man as craftsman), whose activities have a clear ending point (i.e., the production of an artifact). Finally, action, which can go on between people "without the intermediary of things," 14 has to be a central activity for free politics.

One crucial factor that informs this part of Arendt's judgment is that when the mentality of work instead of action dominates politics, we view human beings as "raw material" to be shaped by a particular end or value. In Arendt's example, Plato's Republic introduces the idea that the philosopher-kings should create a hierarchical state to reflect what they consider to be the truth. In this scheme, political actors are a mere means of serving a predetermined truth claim. Such a problem, Arendt notes, also occurs in the modern, secularized context. In the struggles among what Max Weber called "the warring gods," 15 every political actor is

\footnotetext{
${ }^{11}$ Hannah Arendt, “The Great Tradition: II. Ruling and Being Ruled," Social Research 74 (2007): 941-54, at 945.

${ }^{12}$ Hannah Arendt, The Human Condition (Chicago: The University of Chicago Press, 1998), 220-39.

${ }^{13}$ Ibid., 143.

${ }^{14}$ Ibid., 7.

${ }^{15}$ Max Weber, "Science as a Vocation," in From Max Weber: Essays in Sociology, ed. H. H. Gerth and C. Wright Mills (Oxford: Oxford University Press, 1946), 129-58, at 153.
} 
conceived of as a mere "cog" in the machine of ideological war. ${ }^{16}$ Best epitomizing Arendt's concern about work as a way of approaching politics is Machiavelli's and Robespierre's justification of violence for the act of founding: "You cannot make a table without killing trees, you cannot make an omelet without breaking eggs, you cannot make a republic without killing people." ${ }^{17}$

Of course, Arendt is not a pacifist advocating a Kantian "perpetual peace." Even when she mentions "cosmopolitan existence" in her lectures on Kant's political philosophy, Arendt mainly uses that term to caution against the misuse of the idea of humanity. ${ }^{18}$ However, Arendt clearly wants to challenge the idea that politics is all about domination and is inherently violent. For her, "the raison d'etre of politics is freedom, and its field of experience is action." ${ }^{19}$ Her free politics accentuates a political life of talk and argument that takes place in a shared public space with a plurality of individuals, each of whom is unique and has his or her own initiative.

In order to understand Arendt's view that action-driven politics eschews enforcement, domination, or violence, we must attend to the distinctive features of action that foster free politics. Arendt considers action as revelatory—a view some have called "dramaturgical"

\footnotetext{
${ }^{16}$ Hannah Arendt, The Origins of Totalitarianism (New York: Harcourt Brace, 1973), 146.

${ }^{17}$ Hannah Arendt, "What is Authority?" in Between Past and Future: Eight Exercises in Political Thought (New York: Penguin Books, 2006), 91-141, at 139.

${ }^{18}$ Hannah Arendt, Lectures on Kant's Political Philosophy, ed. Ronald Beiner (Chicago: The University of Chicago Press, 1982), 76. For Arendt's views on cosmopolitanism, see Patricia Owens, "Walking Corpses: Arendt on the Limits and Possibilities of Cosmopolitan Politics," in International Relations Theory and Philosophy: Interpretive Dialogues, ed. Cerwyn Moore and Chris Farrands (London: Routledge, 2010), 72-82; and Patrick Hayden, Political Evil in a Global Age: Hannah Arendt and International Theory (London: Routledge, 2009).

${ }^{19}$ Hannah Arendt, "What is Freedom?" in Between Past and Future: Eight Exercises in Political Thought (New York: Penguin Books, 2006), 142-69, at 145.

${ }^{20}$ Richard Wolin, The Politics of Being: The Political Thought of Martin Heidegger (New York: Columbia University Press, 1990), 191, n3.
} 
meaning that through performing "great" words and deeds in public, we reveal our uniqueness and, in so doing, "we insert ourselves into the human world." ${ }^{21}$ For Arendt, however, the disclosure of uniqueness is not "achieved as a willful purpose.",2 One's uniqueness, or who they are, is not revealed in attempts to execute and fulfil what allegedly defines them but only in things they say and do; hence, the "who" to be disclosed always remains hidden from the actors themself. In Arendt's scheme, actors are not those who claim to know some truths about themselves and announce them in public. ${ }^{23}$ In this regard, a form of politics based on disclosive action can prevent or significantly reduce enforcement and domination by avoiding any projection of predetermined truths into the public sphere.

Arendt's accounts of action that emphasize impersonality or self-distance are also undergirded by the obvious fact that to be heard and witnessed, one's speeches and actions need an audience. The associational aspect of action that creates new relationships through constant engagements with others' words and deeds renders action-centered politics distinct from domination. To Arendt, the presence of others means that one does not have full control of one's speeches and actions. The idea of maintaining a willful purpose, then, is not only conceptually incompatible with the performative character of action but also practically not feasible: 'The disclosure of the 'who' through speech, and the setting of a new beginning through action, always fall into an already existing web where their immediate consequences

\footnotetext{
${ }^{21}$ Arendt, The Human Condition, 176.

${ }^{22}$ Ibid., 179.

${ }^{23}$ This aspect of Arendt's thoughts on action removes action-driven politics far from ideological politics. See Patricia Owens, Between War and Politics: International Relations and the Thoughts of Hannah Arendt (Oxford: Oxford University Press, 2007), 16-20; Andrew Schaap, Political Reconciliation (London: Routledge, 2005), 64; and Jonathan Peter Schwartz, "Political Judgment Confronts Ideology: Hannah Arendt's Contribution,” Polity 50 (2018): 485-511, at 502-07.
} 
can be felt." ${ }^{24}$ Given this, action and speech rarely achieve their purpose, but by creating a chain reaction in a web of human relationships, they "produce" stories. $^{25}$

Action-driven politics thus avoids rulership or domination, because once action becomes a central mode of activity for politics, political agents will not force their wills or values onto others but reveal their uniqueness through particular words and deeds in public. In addition, because engagement with others' actions and stories always mediates individual action, action is not fixated on an end. Thus, there is no clear author in action-centered politics but a plurality of individuals who continue to share their perspectives. This way, action-driven politics can help us explore a radical vision of peace beyond rulership.

\section{Problems with Action-Driven Politics}

Critical peace theorists are particularly interested in Arendt's theory of action to articulate agonistic forms of peace that challenge mechanistic peace processes, identify contested yet meaning-making sites of peace in everyday politics, and envision globalized solidarity for nondomination. ${ }^{26}$ But to the extent that it is innovative, Arendt's view of action is also controversial. In fact, Arendt herself maintains a mixed attitude toward action. ${ }^{27}$ To avoid the

\footnotetext{
${ }^{24}$ Arendt, The Human Condition, 184.

25 Ibid.

${ }^{26}$ Audra Mitchell, "Peace beyond Process?" Millennium: Journal of International Studies 38 (2010): 641-64; Annika Björkdahl and Johanna Mannergren Selimovic, "A Tale of Three Bridges: Agency and Agonism in Peace Building," Third World Quarterly 37 (2016): 321-35; and Lars Rensmann, "Grounding Cosmopolitics: Rethinking Crimes against Humanity and Global Political Theory with Arendt and Adorno," in Arendt and Adorno: Political and Philosophical Investigations, ed. Lars Rensmann and Samir Gandesha (Stanford: Stanford University Press, 2012), 129-53.

${ }^{27}$ Margaret Canovan, Hannah Arendt: A Reinterpretation of Her Political Thought (Cambridge: Cambridge University Press, 1992), 133; Dana Villa, Public Freedom (Princeton: Princeton University Press, 2008), 306; and Roy Tsao, "Arendt against Athens: Rereading The Human Condition," Political Theory 30 (2002): 97-123.
} 
mistake of "treating her [works] themselves as little more than haphazard collections of aphoristic dicta," as Roy Tsao warns, we need to expand our interpretive horizons beyond one aspect of her thinking-action — to capture the broad picture her free politics draws and to articulate its implications for peace engagements. ${ }^{28}$

Arendt commentators have questioned if her valorization of action's performative dimension sidelines morality, and if her appeal to acting in concert-and the resulting communal power-undermines the need for individual self-discipline toward a radically agonistic politics. The so-called Kantian and agonistic critiques ${ }^{29}$ highlight in their respective ways these problems Arendt's theory of action faces. These issues are highly relevant to the discourse on peace in that thoughtful peace engagements should not only secure stability by establishing common institutions, but also accommodate the new voice for change each unique individual actor raises in peace processes.

We should note, however, that Arendt herself never fails to notice the challenges action-driven politics encounters. Seeing that intense agonism was accompanied by action among the ancient Greeks, Arendt acknowledges that action can lead to the intensely agonal competition to reveal one's uniqueness or excellence. ${ }^{30}$ A paradigmatic case of this feature of action is found in Achilles" heroic words and deeds that pursue "self-disclosure at the expense

\footnotetext{
28 Tsao, "Arendt Against Athens," 98.

${ }^{29}$ For a Kantian response, see Seyla Benhabib, The Reluctant Modernism of Hannah Arendt (Thousand Oaks, CA: Sage Publication, 1996), 193-98; and Another Cosmopolitanism (Oxford: Oxford University Press, 2008), 13-80. For an agonistic interpretation of Arendt, see Bonnie Honig, Political Theory and the Displacement of Politics (Ithaca, NY: Cornell University Press, 1993), 42-75; and Emergency Politics: Paradox, Law, Democracy (Princeton: Princeton University, 2009), 112-80. For an overview of Kantianism and agonism, see Garrett Wallace Brown, Grounding Cosmopolitanism: From Kant to the Idea of a Cosmopolitan Constitution (Edinburgh: Edinburgh University Press, 2009); and Mark Wenman, Agonistic Democracy: Constituent Power in an Era of Globalization (Cambridge: Cambridge University Press, 2013).

${ }^{30}$ Hannah Arendt, "Philosophy and Politics," Social Research 71 (2004): 427-54, at 435.
} 
of all other factors." ${ }^{31}$ In Arendt's view, such a highly agonistic form of action needs to be "tamed." 32 If far from Kantian proceduralism, Arendt nonetheless appreciates the function of laws as a stabilizing force for the reliable appearance of action. Thus, she mentions that "the territorial boundaries which protect and make possible the physical identity of a people, and the laws which protect and make possible its political existence, are of such great importance to the stability of human affairs." 33

At the same time, Arendt is concerned about the revelatory quality of action. In her judgment, setting up a communal context for action has dual effects. The foundation of the polis "enabled men to spend their whole lives in the political realm, in action and speech,"34 creating a stable context that moderated the fleeting and unpredictable features of action. This in turn meant that the "highly individualistic" pre-polis form of action, in which speech drew attention to the "greatness" of one's deeds, was replaced by a more collective form in Athens. ${ }^{35}$ Subsequently, speech as a form of action was transformed into a means of persuasion. ${ }^{36}$ Yet, Arendt notes that in "all other performances [than action] speech plays a subordinate role, as a means of communication. ${ }^{37}$ Her concern is that once action becomes bound to the public, action and speech are no longer concurrent. This increases the danger of speech becoming "merely" communicative, a form of deliberation concerned only with means. That is, speech

\footnotetext{
${ }^{31}$ Arendt, The Human Condition, 194.

${ }^{32}$ Canovan, Hannah Arendt, 143.

${ }^{33}$ Arendt, The Human Condition, 191.

${ }^{34}$ Ibid., 25.

${ }^{35}$ Ibid., 194.

${ }^{36}$ Ibid., 26.

${ }^{37}$ Ibid., 179.
} 
can only play a subordinate role as an instrument of persuasion for communal purposes, losing the revelatory quality the speech adorning a spontaneous action possesses.

Such ambivalence toward action found in Arendt's thinking prompts us to question our initial conclusion that action is the best method to generate free politics and that we must resist work's becoming a central mode of politics. Recall that work makes or fabricates things according to the means-and-ends reasoning, and "[an] element of violation and violence is present in all fabrication." ${ }^{38}$ But, because action itself is initiatory, boundless, and thus lacking stability, we need a way of moderation, a quality Arendt considers "one of the political virtues par excellence. ${ }^{39}$ Here, we must note another aspect of Arendt's thoughts on work. Arendt argues that the activity of work carries the important feature of worldliness because work creates the world that outlasts and transcends each individual life. ${ }^{40}$ By demarcating an artificial world from all natural surroundings, work provides some measures according to which humans achieve (relative) permanence and durability. Homo faber transforms nature into something stable and solid, a "man-made home," without which human beings are left to "swing relentlessly in the circle of their own biological movement." beneficial for free politics in the same activity of work that we initially considered solely detrimental to it. In the next section, I will further articulate Arendt's views on work and action, as this interpretive area is highly complex and controversial, before showing how this discussion provides useful insights for peace engagements.

\footnotetext{
${ }^{38}$ Arendt, "What is Authority?" 111.

${ }^{39}$ Arendt, The Human Condition, 191.

${ }^{40}$ Ibid., 7.

${ }^{41}$ Ibid., 137.
} 
Initiation, Demarcation, and Balancing

Arendt's concern for stability does not mean that she wants to establish work as a central mode of activity for free politics, repudiating action. Arendt is consistent about the limitations of work as an activity for free politics. As Dana Villa points out, Arendt thinks "work does not humanize nature." ${ }^{42}$ It only creates a non-natural space, the world, which stands between nature and humanity. Arendt also argues that the world originally disclosed through work, unless it is "overlaid" with the "subjective in-between" of words and deeds, cannot be a space of freedom. ${ }^{43}$ Without action's constant inputs, the man-made home is vulnerable to institutional sclerosis. Arendt clarifies this point by delineating how the limit-granting activity of work degenerates into labor, the activity driven by the cyclical movement of nature. The instrumentality-driven feature of work drives homo faber to treat all finished products as use objects, another means to achieve an end. ${ }^{44}$ This mindset eventually results in a degradation of all things of the world into means and the loss of their intrinsic and independent value. Because "the productive and limited instrumentality of fabrication change[s] into the limitless instrumentalization of everything that exists," ${ }^{45}$ Arendt affirms that work alone is inadequate for maintaining the world. Although work provides durability by setting limits on the cyclical life process, the very principle behind work that initially made this possible (i.e., instrumentality) is "prone to collapse back into the circularity that had been characteristic of labor." ${ }^{46}$ To

\footnotetext{
${ }^{42}$ Dana Villa, Arendt and Heidegger: The Fate of the Political (Princeton: Princeton University Press, 1996), 27.

${ }^{43}$ Arendt, The Human Condition, 182-83.

${ }^{44}$ Ibid., 153-59.

${ }^{45}$ Ibid., 157.

${ }^{46}$ Patchen Markell, “Arendt's Work: On the Architecture of The Human Condition," College Literature 38 (2011): 15-44, at 28.
} 
prevent this from happening, the world created by artifice needs consistent input of actions. It should not remain the site of productive comportment; it must be a space for disclosive action.

Given this, Arendt's thinking draws on the dynamic relationship between work and action. Confirming the need for a symbiotic interaction between demarcating work and disruptive action, Arendt points to a duality of tasks that free politics must perform: although we should establish common institutions to secure stability for politics, those institutions also ought to accommodate new voices and opinions for change. Otherwise, public institutions would be readily ossified and turn into a means serving an arbitrary end and a cyclical life process (manifested in modern consumerist culture and the neoliberal market economy ${ }^{47}$ ). This important insight, however, is not limited to the preservation of the already existing public world. It also extends to the very founding of a new constitution. In the Arendtian scheme, the creation of common institutions is never left to a group of political elites or bureaucrats.

For some scholars, Arendt considers the act of creating a new space for politics to be pre-political. ${ }^{48}$ Their interpretation is not completely ungrounded in Arendt's works. In The Human Condition, Arendt mentions that legislation or lawmaking, like the building of the walls of the city, does not belong to the mode of action but to work, or craftsmanship. According to this view reflecting the Greek perception of law (nomos), action is clearly separated from the

\footnotetext{
${ }^{47}$ Patricia Owens, "Human Security and the Rise of the Social," Review of International Studies 38 (2012): 547-67.

${ }^{48}$ Hans Lindahl, "Give and Take: Arendt and the Nomos of Political Community," Philosophy \& Social Criticism 32 (2006): 881-901, at 883; Elizabeth Frazer and Kimberly Hutchings, "On Politics and Violence: Arendt contra Fanon," Contemporary Political Theory 7 (2008): 90-108, at 102; and Christopher Finlay, "Hannah Arendt's Critique of Violence," Thesis Eleven 97 (2009): $26-45$, at 38 .
} 
formation of legal boundaries because "the laws ... [are] not the results of action but products of making." 49 At one point, Arendt makes the misleading remark that "acting and speaking men need the help of homo faber in his highest capacity, that is, the help of the artist." ${ }^{, 50}$ On the surface, this sounds as if creating a new space for subsequent actions were a privileged instance of artwork by a (demiurgic) artist. Understood this way, Arendt's thoughts on action have little or no relevance to the dimension outside the clearly demarcated arena of domestic politics because that dimension is pre-political..$^{51}$

In On Revolution, however, Arendt makes explicit that the act of founding a new body politic should not be a work of art by a single artist or a potent dictator. Such a mode of thinking, Arendt argues, dominated the French revolutionaries, such as Robespierre, who made use of violence as they fashioned themselves in the image of "architects" constructing a new polity out of human material, in a manner similar to that of an artist who creates a new work of art. ${ }^{52}$ By way of contrast, Arendt refers to the American Revolution, in which debate, deliberation, and argument-not the violence that accompanies a war of liberation from oppression-occurred prior to the constitutional foundation of a new space of freedom. Her broad point here is that a founding act, if accompanied by communal power, obviates any use

${ }^{49}$ Arendt, The Human Condition, 194.

${ }^{50}$ Ibid., 173.

${ }^{51}$ I do not directly deal with Arendt's engagement with the Greek nomos and the Roman lex here. For this topic of concern, see Christian Volk, "From Nomos to Lex: Hannah Arendt on Law, Politics, and Order," Leiden Journal of International Law 23 (2010): 759-79, at 774-78; and Shinkyu Lee, "The Lex of the Earth? Arendt's Critique of Roman Law," Journal of International Political Theory (Ahead of print, January 2020): 1-18, at 5-10.

https://doi.org/10.1177\%2F1755088219898237.

${ }^{52}$ Arendt, On Revolution, 201. Villa makes a powerful case that such a "productionist" metaphysics actually belongs to Heidegger. See Villa, "Arendt, Heidegger, and the Tradition," 995-98. 
of violence. Power, for Arendt, is not one's ability to dominate and do violence to others. ${ }^{53} \mathrm{It}$ is only "engendered by action and kept by promises." 54 This reformulation of power enables Arendt to see that as long as people keep intact the power that springs up among them, "they are already in the process of foundation, of constituting a stable worldly structure to house, as it were, their combined power of action." 55

If action is the seed of power, the consistent presence of which is a precondition for founding a new space for politics, treating action as irrelevant until the founding is complete cannot be Arendt's intent. Of course, a founding act is not boundless; instead, it sets boundaries or institutional structures that help us hold at bay natural and quasi-natural forces threatening to overrun the world. For Arendt, it is an act of demarcating an artificial world from all-natural surroundings or establishing what she calls "the human artifice" - the artificial world of civilization. After all, the founding act produces a constitution that is not amorphous but "a written document, an endurable objective thing." 56 This aspect of Arendt's thoughts on constitution-building leads some to argue that the founding act delineated in On Revolution never goes beyond a model of fabrication or the mindset of work. ${ }^{57}$ However, what initiates the founding act, according to Arendt, is power formed at the grassroots level; such a task is not left to a single dictator or political elites. For Arendt, an action that later gives rise to a communal power is not driven by a blueprint; acting is neither a projection of one's will or

\footnotetext{
${ }^{53}$ Arendt, On Revolution, 132-70; and On Violence, 44-56.

${ }^{54}$ Arendt, On Revolution, 167.

${ }^{55}$ Ibid., 166.

${ }^{56}$ Ibid., 148.

${ }^{57}$ John MacGowan, "Must Politics be Violent? Arendt's Utopian Vision," in Hannah Arendt and the Meaning of Politics, ed. Craig Calhoun and John McGowan (Minneapolis: University of Minnesota Press, 1997), 263-96, at 275.
} 
end nor a reflection of historical necessity. In addition, Arendt argues that the act of constitution is not permanently completed. The word "constitution" connotes not only "the Constitution as a written document" but also "the constituting act ... by which a people constitutes itself into a body politic." ${ }^{58}$ The founding act, which Arendt characterizes with "augmentation," is both a complete document and an ongoing activity—a combined result of work and action. ${ }^{59}$

Critics also question if establishing a new space for free politics in Arendt's fashion "will necessarily form boundaries to and limits on the possibility of new action that follows this founding moment." ${ }^{60}$ Yet as Jeremy Waldron points out, Arendt's consistent emphasis on stability and change in her theoretical formulation of constitution-building comes from her realistic observation that the rules that constitute the public world must pre-exist individuals taking action and forming power in that world. "Every man," Arendt notes in On Violence, “is born into a community with pre-existing laws which he 'obeys' first of all because there is no other way for him to enter the great game of the world." 62 This is not to suggest that law determines the content of politics (or the game). It only means that public law, like the constitution, provides an institutionally articulated space of freedom in which individuals'

\footnotetext{
${ }^{58}$ Arendt, On Revolution, 196.

${ }^{59}$ Ibid., 194.

${ }^{60}$ Alan Keenan, "Promises, Promises: The Abyss of Freedom and the Loss of the Political in the Work of Hannah Arendt," Political Theory 22 (1994): 297-322, at 309.

${ }^{61}$ Jeremy Waldron, “Arendt's Constitutional Politics," in The Cambridge Companion to Hannah Arendt, ed. Dana Villa (Cambridge: Cambridge University Press, 2000), 201-19, at 213.

${ }^{62}$ Arendt, On Violence, 97.
} 
actions are displayed reliably and felt in public. ${ }^{63}$ Thus Arendt sees the law's role as functional: it serves to restrain the unpredictability of action within minimal limits.

The concern that public law and institutions restrain individual agency closely relates to how one understands law's nature and scope. Here, we must note that Arendt's thinking is far from legalism. A newly constituted space, for her, never remains intact. Arendt does not think legal limits serve as entirely reliable safeguards against action. ${ }^{64}$ Founding and modifying institutions in the Arendtian way of non-violence and non-domination must be a complex process. In On Revolution, Arendt writes, "The way the beginner starts whatever he intends to do lays down the law of action," the principle that inspires others to follow the initiator and create a joint enterprise. ${ }^{65}$ The principle of action that invites others' participation is never what one can fully predict and calculate in the first place. A radical change does happen in this scheme, if not in an abrupt way. It is entirely possible that new principles of action that are less and less harmonious with the existing criteria of law emerge and attract the majority of the people. At one point, the gap between existing laws and public culture is drastically wide, and the desire for change is vividly strong. Insofar as power for a new joint enterprise is consistently present, Arendt expects that people will engage in founding a new space for free politics.

As such, for Arendt, action is crucial in both founding and preserving a space for free politics. Without action's consistent inputs, institutional ossification is unavoidable. Moreover,

\footnotetext{
63 "Politics," Arendt says, "deals with men, nationals of many countries and heirs to many pasts; its laws are positively established fences which hedge in, protect, and limit the space in which freedom is not a concept, but a living, political reality." Hannah Arendt, "Karl Jaspers: Citizen of the World," in Men in Dark Times (New York: Harcourt, 1968), 81-94, at 81-82. See also Arendt, The Human Condition, 57.

${ }^{64}$ Arendt, The Human Condition, 191.

${ }^{65}$ Arendt, On Revolution, 205.
} 
unless constitution-building is preceded by a communal power engendered by action and kept in existence through mutual promise, it is vulnerable to devolving into violence. But Arendt also sees that action itself is disruptive, fleeting, and boundless. Thus, although action remains a decisive element for free politics, it also requires an institutionally articulated space that helps it appear reliably. In the end, what we gain from Arendt's discussion of the vita activa is a dynamic relationship between work and action.

\section{Worldly Realism}

Behind Arendt's complex thoughts on the relationship of action and work lies her deep appreciation of worldliness. As a way of synthesizing what I have discussed so far, I elucidate this attitudinal quality and identify a distinctive form of realism in Arendt's thinking that can serve to show the limitations of the liberal and critical peacebuilding approaches.

To Arendt, the area in which the activities of work and action are conjoined, despite their fundamental difference, is the public world. Arendt thinks work and action (or culture and politics, as she puts them elsewhere) are both phenomena of "the world." relationship between the two activities attains a special meaning in Arendt's idea of worldliness. Arendt brings sharp clarity to this idea when describing the public realm. The public realm for her must have phenomenological and spatial features: While the phenomenological sense of the public realm is concerned with how agonistic individuals appear in public, along with others' recognition of their performances, the spatial aspect of the public realm emphasizes that there is a common world located among all public participants. These two features of the public realm demonstrate Arendt's equal interest in agonistic action and stable institutions. Thus, the

\footnotetext{
${ }^{66}$ Hannah Arendt, "Culture and Politics," in Reflections on Literature and Culture, ed. Susannah Young-ah Gottlieb (Stanford: Stanford University Press, 2007), 179-202, at 197.
} 
phenomenological aspect of the public realm suggests that agonistic action does not occur without the presence of others, and the spatial aspect of the public realm emphasizes a relatively stable world of institutions enabling the reliable appearance of action. To be in this world, for Arendt, is to accommodate both aspects of the public realm. This in turn suggests that the public realm in Arendt's sense avoids both of the following situations: first, that public law and institutions are so far from people's experience that they are seen as alien things imposed upon a citizenry rather than the architecture of citizenship, and second, that individuals' competition is so intense that public institutions are endangered and the common world of experience disappears. Worldliness is manifested only when we seek to balance agonistic action and stable institutions.

Arendt's idea of worldliness helps us understand her special sense of realism. Through this "worldly realism," we remain and engage in the world of reality and still find ways to defy the status quo of politics. The human artifice of institutions that we have established through acting together is not dismissed right after its foundation; instead, its constituents preserve and care for it. However, the stable common world is not tightly enclosed because it is composed of citizens whose constant engagement in agonistic action and sharing of diverse opinions revise its criteria of political/legal judgment over time. ${ }^{67}$ Important here is the desire to preserve the public world that grants us reality, ${ }^{68}$ as this desire to sustain and cultivate the world serves to resist the overreach of agonism and the overemphasis on status-quo politics,

\footnotetext{
${ }^{67}$ For Arendt, the change in the public world occurs "gradually and imperceptibly, so that the men who live in it experience it as being more durable than themselves." See Margaret Canovan, The Political Thought of Hannah Arendt (London: J. M. Dent \& Sons Ltd, 1974), 83. ${ }^{68}$ Arendt argues that reality is established only when individuals constantly appear in the public realm. See The Human Condition, 50-51.
} 
thereby modifying the conventional senses of both progressivism and conservatism. ${ }^{69}$ Equally decisive is the ambiguity that allows for two features of work (instrumentality-driven and stability-generating) to exist on a continuum. Stability-generating institutions may develop into instruments serving an arbitrary will or end, as a more robust version of the good life surreptitiously involves the process of establishing a common world of partners. Having such a danger in mind, citizens deeply informed by worldly realism seek to reflect law and institutions in their actual lives and promote initiatory actions and new opinions that create gradual change as they are inserted into the existing arrangements of public judgment. Finally, realism of this kind highlights the need for balance for free politics. Rather than entertaining an imaginary point of complete equilibrium between the demands of agonistic action and common institutions in the most abstract sense, Arendt's worldly realism focuses on the balancing activity itself. The ambivalence toward the activity of work implied in Arendt's sense of realism directs our attention to the real world of politics, where the task of free politics remains incomplete, and thus balancing is always necessary.

Applied to peace engagements, worldly realism assists us in recognizing two dangers. On one hand, establishing common institutions for peace can be an arbitrary projection of a tyrannical will. On the other hand, a politics of resistance to endlessly decolonize disciplinary/hegemonic power in conflict/peace processes may eradicate the objective, public world through which "worldly reality [can] truly and reliably appear." "70 Avoiding these dangers, Arendt's worldly realism urges us to diagnose the extent to which one type of danger prevails over the other, correct the condition by balancing it, and remain alert to any encroachment of

\footnotetext{
${ }^{69}$ Arendt, On Revolution, 215.

${ }^{70}$ Arendt, The Human Condition, 57.
} 
either danger. Peace in this scheme is always fragile. It emerges through the constant struggles to balance action and institutions in the real world of politics.

\section{Building Political Communities of Peace}

This formulation of a worldly vision of peace both acknowledges the challenges and difficulties that lie in any serious endeavors to build common institutions for peace and brings a normative parameter for peacebuilding by offering a nuanced insight into the local. Contemporary peacebuilding raises two fundamental issues: 1) the relationship between "internal" and “external" peace practitioners, often characterized as donors and recipients or as the global and the local, and 2) the nature of the local, specifically how the local is and should be constituted. These issues are different but not completely separate. For successful and sustainable peacebuilding, "external" mediators and "internal" conflict parties alike need some sort of normative parameters regarding how to constitute local communities fostering peace and reducing violence. In fact, as I will detail, different ways of conceiving of the local affect liberal and critical positions on peace intervention. Arendt's worldly realism, accommodating both agonistic action and institutional stability, sees the local as neither a completely confined space nor a site of sheer indeterminacy. In this way, her thinking cautions liberal peacebuilding against projecting strong institutional criteria onto local peace processes, while providing direction and meaning to the politics of resistance envisioned in critical peacebuilding.

The liberal peace approach is arguably the most dominant paradigm in current

peacebuilding discourse. Most policy documents relating to international peace and security issues contain some of the liberal peace agenda, accentuating the connection between 
democracy, state institutions, and neoliberal economic politics. ${ }^{71}$ For radical critics of peacebuilding, especially those informed by neo-Marxist structuralist frameworks, liberal peace is merely a projection of Western states' economic, security, and political interests. ${ }^{72}$ As Catherine Goetze and Dejan Guzina point out, however, there are two different streams within liberal peacebuilding-functionalist and human security oriented. Unlike the former, which is "mainly concerned with the effects of civil wars and weak states on the national security of western/northern industrial states," the human security approach takes a moral stand on peacebuilding and conceives of peace intervention as an ethical response to suffering. ${ }^{73}$ The distinction suggests that in criticizing the liberal peace approach, we need to be clear about the nature of critique-namely, which aspect of liberal peace we problematize and to what extent.

As her deep concern about the miserable fate of the stateless people in The Origins of Totalitarianism demonstrates, Arendt is not dismissive of some liberal values, such as human rights. ${ }^{74}$ But her conception of free politics renders Arendt sensitive to domination and cautious about bringing predetermined moral criteria into the dimension of the political, where public talk and mutual deliberation always play a central role. Viewed through an Arendtian

\footnotetext{
${ }^{71}$ United Nations, "High-Level Panel on Threats, Challenges and Change: Report of the Secretary-General," A/59/565 (December 2, 2004), at https://digitallibrary.un.org/record/536113? In=en; and International Commission on Intervention and State Sovereignty, The Responsibility to Protect (Ottawa: International Development Research Center, 2001).

${ }^{72}$ Michael Pugh, “The Political Economy of Peacebuilding: A Critical Theory Perspective," International Journal of Peace Studies 10 (2005): 23-42; Tim Jacoby, "Hegemony, Modernization, and Post-War Reconstruction," Global Society 21 (2007): 521-37; and Julien Barbara, "Rethinking Neo-Liberal State Building: Building Post-Conflict Development States," Development in Practice 18 (2008): 307-18.

${ }^{73}$ Catherine Goetze and Dejan Guzina, "Peacebuilding, Statebuilding, NationbuildingTurtles All the Way Down?” Civil Wars 10 (2008): 319-47, at 328-29.

${ }^{74}$ Arendt, The Origins of Totalitarianism, 269-90.
} 
lens, then, creating a human rights-oriented governance all over the world is a much more vulnerable task than liberal scholars acknowledge. In Arendt's judgment, humanity alone (or any governance based on the idea of humanity) is not enough to guarantee the right to have rights or to meet the demand "to live in a framework where one is judged by one's actions and opinion." 75 The most fundamental deprivation of human rights, Arendt thinks, occurs when there is no tangible place available that "makes opinions significant and actions effective.", Humanity is not a natural quality designating the human race "in the same way as animals belong to a specific animal species." ${ }^{77}$ On the contrary, it is achieved through constant public activities among one's peers in an institutionally articulated framework.

Seen from this perspective, grounding peacebuilding efforts in the abstract idea of "global humanity" 78 without securing or attending to tangible local contexts that facilitate the reliable appearances of individuals' actions among their peers is problematic. Even worse, pursuing a world government or a global regulatory system for human rights can lead to tyranny and depoliticization. This sensitivity found in Arendt's thinking is not manifest in the liberal peace approach.

Of course, since the shortcomings of the liberal top-down model of peacebuilding have become apparent through the debacles of the Iraq and Afghanistan interventions, there has been "something of a 'rediscovery' of the local." 79 Now, liberal peace scholars too see the needs to empower local capacities for peacebuilding and to enable local resources to

\footnotetext{
${ }^{75}$ Ibid., 296-97.

${ }^{76}$ Ibid., 296.

${ }^{77}$ Ibid., 302.

${ }^{78}$ Bruce Mazlish, The Idea of Humanity in a Global Era (New York: Palgrave, 2009), 17-29.

${ }^{79}$ Mac Ginty, "Where Is the Local?" 845.
} 
accomplish such a task. ${ }^{80}$ Yet recent liberal engagement with the local has been "shallow." 81 This problem occurs because the strong conviction that human rights must be "cosmopolitan" norms that apply anytime and everywhere devalues a strenuous dialogue regarding indigenous sources of conflict and peace. ${ }^{82}$ Rather, the focus of such an engagement with the local usually lies in developing particular strategies for promoting values envisioned in the liberal agenda. The problem of the shallow local turn is undergirded by the extant unequal power structure in global-local relations. Oliver Richmond has effectively shown that the financial reliance of NGOs on liberal peace donors restrains the scope of their work.$^{83}$ Civil society actors, trapped in such a power imbalance, fail to engage with the local as it is, mainly in relationship to strategies to transform local communities' political and economic structures into a form that is compatible with liberal peace and governance.

Arendt's thinking, which I have characterized as "worldly realism," anticipates the problems of domination and depoliticization that the liberal peace attempt entails. Simply put, the liberal approach is too ambitious. Its premise that the local is a mere function of abstract moral standards is equally problematic. Arendt's thoughts draw attention to the "micro" level of politics, at which citizens' agonistic actions are actually felt, and their diverse opinions are constantly exchanged. Unless peace practitioners revive such a vibrant politics at the local level, any lofty claim of peace remains ideational and vulnerable to misuse for domination. Owing

\footnotetext{
${ }^{80}$ See Doyle and Sambanis' "peacebuilding triangle" in Making W ar \& Building Peace, 27-68, and Roland Paris's "strategic liberalization" in At War's End: Building Peace after Civil Conflict (Cambridge: Cambridge University Press, 2006), 151-211.

${ }^{81}$ Mac Ginty, "Where Is the Local?" 846.

${ }^{82}$ See, for this observation, Garrett Wallace Brown, “The Constitutionalization of What? Global Constitutionalism 1 (2012), 201-28, at 224-26.

${ }^{83}$ Oliver Richmond, "Emancipatory Forms of Human Security and Liberal Peacebuilding," International Journal 62 (2007): 459-78, at 463-72.
} 
to its emphasis on a form of grassroots participation rather than on a top-down legislative imposition of ostensibly universal norms, Arendt's thinking appears to be much more congenial to critical peacebuilding characterized as a "bottom-up" approach to peace. ${ }^{84}$

From the perspective of Arendt's worldly realism, however, both the hybrid and radical streams of critical peacebuilding fail to see the crucial role of public institutions to render ruling and domination inoperative. The central topic that has occupied critical peace scholars is how to reflect local differences and increase the involvement of local parties in peace processes. The danger found in the early attempt to pursue a locally empowered peace is to romanticize the local, as it idealistically characterizes local people as a unique entity imbued with wisdom and resourcefulness for cultivating peace. ${ }^{85}$ To avoid this, critical peace scholars have turned to the hybridity found in complex interconnectedness among multiple peace actors and networks as a way of challenging the binary between the global and the local and shifting attention to the performative dimension "external" and "internal" actors mutually constitute in peacebuilding. ${ }^{86}$ But critics note that hybrid peace draws on arbitrary standards to distinguish positive and negative forms of hybridity. The proponents of hybrid peace, according to the critique, concede that particularistic, ethnocentric, and divisive views found among some of the local population cannot contribute to the emancipatory process of

\footnotetext{
${ }^{84}$ Roger Mac Ginty, "Everyday Peace: Bottom-Up and Local Agency in Conflict-Affected Societies," Security Dialogue 45 (2014): 548-64.

${ }^{85}$ Anja Nygren, "Local Knowledge in the Environment-Development Discourse: From Dichotomies to Situated Knowledges," Critique of Anthropology 19 (1999): 267-88, at 274-75; and Alean Al-Krenawi and John R. Graham, "Conflict Resolution through a Traditional Ritual among the Bedouin Arabs of the Negev," Ethnology 38 (1999): 163-74.

${ }^{86}$ Oliver Richmond, "De-Romanticising the Local, De-Mystifying the International: Hybridity in Timor Leste and the Solomon Islands," Pacific Review 24 (2011): 115-36; David Campbell, National Deconstruction: Violence, Identity, and Justice in Bosnia (Minneapolis: University Minnesota Press, 1998), 30; and Roger Mac Ginty, "Hybrid Peace: The Interaction between Top-Down and Bottom-Up Peace,” Security Dialogue 41 (2010): 391-412, at 392.
} 
peacebuilding. ${ }^{87}$ In acknowledging this, hybrid peace theorists treat some form of local agency as more "civil" or "authentic" than others, ${ }^{88}$ which can create selection bias in research and the marginalization of certain actors in peace processes. ${ }^{89}$ This aspect of hybrid peace renders its intended departure from liberal peace much less radical than its proponents claim. Critics of hybrid peace call for fully acknowledging that any explanatory distinctions between authentic and unauthentic agency on the basis of emancipation, however subtle and reflexive they might be, must fail to capture the complexity that lies in peace processes. ${ }^{90}$ The source of this radical critique lies in the alterity of the local, and this closely relates to issues regarding the local's nature. If any attempts to formulate a local agency for peace inevitably result in domination and marginalization, the only way to avoid this problem is to treat the local as an open site of contestation. Contra Arendt's recognition of the need to establish and sustain common institutions for free politics beyond domination, radical peace scholars emphasize that the local is ever-changing. Owing to the elusive dimension of locality, they argue that constituting the objective, public world is futile and identifying a local form of agency

\footnotetext{
${ }^{87}$ Rick Fawn and Oliver Richmond, "De Facto States in the Balkans: Shared Governance versus Ethnic Sovereignty in Republika Srpska and Kosovo," Journal of Intervention and Statebuilding 3 (2009): 205-38; and Oliver Richmond and Audra Mitchell, "IntroductionTowards a Post-Liberal Peace," in Hybrid Forms of Peace: From Everyday Agency to PostLiberalism, ed. Oliver Richmond and Audra Mitchell (New York: Palgrave, 2012), 1-38, at 910.

${ }^{88}$ Oliver Richmond, "A Post-Liberal Peace: Eirenism and the Everyday," Review of International Studies 35 (2009): 557-80, at 572.

${ }^{89}$ Elisa Randazzo, “The Paradoxes of the 'Everyday': Scrutinizing the Local Turn in Peace Building," Third World Quarterly 37 (2016): 1351-70, at 1355-58; and Jonas Wolff and Lisbeth Zimmermann, "Between Banyans and Battle Scenes: Liberal Norms, Contestation, and the Limits of Critique," Review of International Studies 42 (2016): 513-34, at 522.

${ }^{90}$ Graef, Practicing Post-Liberal Peacebuilding, 30-32; Suthaharan Nadarajah and David Rampton, "The Limits of Hybridity and the Crisis of Liberal Peace," Review of International Studies 41 (2014): 49-72, at 57-60; and Meera Sabaratnam, "Avatars of Eurocentrism in the Critique of the Liberal Peace,” Security Dialogue 44 (2013): 259-78, at 267-68.
} 
conducive to peace is impossible. Alternatively, they call for peace practitioners to appreciate unpredictable forms of peace engagement stemming from the "friction" between global-local encounters and pursue "the constant pluralization of subjects and ideas."

Although the two approaches in critical peacebuilding — hybrid and radical—differ in their critique, they agree on the goal of critique: revealing hidden power in conflict/peace processes. Indeed, the ability to bring into focus unnoticed power operations in the everyday contexts of peacebuilding is the clear advantage of such critical engagements. The expectation is that through a constant process of resisting and negating subjects and ideas of peace, conflict parties and mediators become cognizant of various biopolitical strategies of power in the settings of everyday peace and eschew the error of projecting arbitrary solutions onto others. ${ }^{92}$ Remaining a site of sheer contestation or indeterminacy, the local decouples itself from the global. With this radical rendition of locality, critical peacebuilding seeks to overcome the dominant neoliberal framework that sets the terms of the construction and relations of the global and the local. That said, this approach is predicated upon the idea that some kind of base of power exists that no institutions can alter or contain. Here, law and institutions, as they are constantly colonized by disciplinary power and biopolitical strategies, are mere means of domination. This viewpoint certainly helps peace practitioners increase sensitivity to hidden power operations in the everyday contexts of peace. But critical peacebuilding's skepticism

\footnotetext{
${ }^{91}$ Björkdahl and Höglund, "Precarious Peacebuilding," 294; Gearoid Millar, Jaïr van der Lijn, and Willemijn Verkoren, "Peacebuilding Plans and Local Reconfigurations: Frictions between Imported Processes and Indigenous Practices," International Peacekeeping 20 (2013): 137-43; and Pol Bargués-Pedreny, "Connolly and the Never-Ending Critiques of Liberal Peace: From the Privilege of Difference to Vorarephilia," Cambridge Review of International Affairs 30 (2017): 216-34, at 228.

${ }^{92}$ Oliver Richmond, "Resistance and the Post-Liberal Peace," Millennium: Journal of International Studies 38 (2010): 665-92, at 685-89; and Laura Zanotti, "Governmentality, Ontology, Methodology: Re-Thinking Political Agency in the Global World," Alternatives: Global, Local, Political 38 (2013): 288-304, at 297-99.
} 
toward institutions poses problems for securing what Arendt calls "lasting institutions" that provide spaces for action and public freedom and make human civilization possible. ${ }^{93}$

In contrast to critical peace theorist Roger Mac Ginty's claim that "substantial parts of human agency ... [operate] outside of statist or institutional domains," ${ }^{, 44}$ Arendt argues that only by appearing in the public world can we be fully human. ${ }^{95}$ Her worldly realism suggests that the public realm should have both phenomenological and spatial features that meet the equal demands of agonistic action and institutional stability. To Arendt, the human artifice of institutions makes action reliably appear by providing stability; it also protects us from natural or quasi-natural forces, such as those generated by the capitalist system of production and consumption. ${ }^{96}$ This aspect of Arendt's thinking prompts some to claim that her conception of the public world is overly formalistic and conservative. ${ }^{97}$ However, we should note that the res publica Arendt envisions is not solely formalistic, as it combines the demands of both stable institutions and agonistic action for free politics. ${ }^{98}$ Arendt thinks, as I discussed at length in the previous section, that formal institutions need action's consistent inputs, without which their ossification is unavoidable. Likewise, action needs stable institutions for its reliable

\footnotetext{
${ }^{93}$ Arendt, On Revolution, 220, 174; and The Human Condition, 197.

${ }^{94}$ Mac Ginty, "Where Is the Local?” 848. See also Oliver Richmond, “The Problem of Peace: Understanding of the 'Liberal Peace," Conflict, Security \& Development 6 (2006): 291314, at 293-300; and Simon Robins, "An Empirical Approach to Post-conflict Legitimacy: Victims' Needs and the Everyday," Journal of Intervention and Statebuilding 7 (2013): 45-64, at 51.

95 Arendt, The Human Condition, 179.

${ }^{96}$ See Canovan, Hannah Arendt, 32.

${ }^{97}$ Honig, Political Theory and the Displacement of Politics, 118-23.

${ }^{98}$ Margaret Canovan, "Politics as Culture: Hannah Arendt and the Public Realm," in Hannah Arendt: Critical Essays, ed. Sandra K. Hinchman and Lewis P. Hinchman (Albany: State University of New York Press, 1994), 179-206, at 186.
} 
appearance. Arendt's dual emphasis on action and institutions comes with her concern about the excess on either side of free politics. Hence, she qualifies the scopes of both law and action: The sole purpose of a constitution is not to replace or remove politics but to facilitate it by providing a legally and institutionally articulated space of freedom. But intensely agonistic action also needs to be tamed, and thus action should have a broad constitutional referent to qualify as political. ${ }^{99}$

This dual emphasis on action and institutions for free politics and their dynamic relationship in worldliness suggests that "worldly" peace engagements should be both formal and informal. Peace does not come about through checking a set of regulations among conflict parties. Building peace is not like a judicial review. Instead, we might achieve peace through worldly efforts to balance the demands of stability and change, or those of demarcating institutions and initiatory action for free politics. Indeed, a worldly peace brings us far more than a negative peace-the mere absence of violence-as it helps us not only eschew enforcement and domination but also establish public freedom and human civilization. From this perspective, the problem with critical peacebuilding lies in its failure to see that, although formal law and institutions might be instruments serving an arbitrary will or end, they are also a bulwark against natural and quasi-natural destructive forces and a medium through which human beings attain public freedom without domination.

By contrast, peace engagements driven by worldly realism would embrace the ambiguity the two features of work (instrumentality-driven and stability-generating) generate and reflect the resulting dynamism between agonistic action and stable institutions. Rather

${ }^{99}$ Dana Villa, Politics, Philosophy, Terror: Essays on the Thought of Hannah Arendt (Princeton: Princeton University Press, 1999), 118. 
than treating the local as "a sphere of activity that is constantly being made and remade," ${ }^{100}$ a worldly realism approach would see the local as the dimension in which the needs of action and institutions, and their balancing, are necessary for "quality peace."101 Such an insight into the constitution of the local, as suggested earlier, offers a normative parameter for peace intervention: "external" conflict meditators should not only seek to enable "internal" conflict parties to raise their different voices in public, but also help them align their disruptive yet creative voices with a desire to found and sustain common institutions. Specific strategies of worldly peacebuilding in the actual contexts of politics remain to be further articulated. However, peace intervention with this orientation clearly differs from the liberal hubris of projecting strong moral and institutional criteria onto the people in peace processes. It also seeks to avoid the radical path of critical peace that promotes awareness of hidden disciplinary powers in peacebuilding yet faces the never-ending claims of resistance and negation, leading to the skeptical view that all peacebuilding efforts are exclusionary and undesirable.

\section{Conclusion}

The recent "local turn" in peacebuilding rightly calls for empowering the local agency for peace. Liberal and critical peace theories explore ways of engaging with the local in peace processes. Yet both theoretical positions maintain problematic assumptions about the nature of the local and how local communities should be constituted. For liberal peace, a clear guideline for peace is established by its moral and institutional values, which renders the approach's turn to the local shallow. In contrast, the critical peace approach puts greater emphasis on the informal,

\footnotetext{
100 Mac Ginty, "Where Is the Local?” 851.

101 Peter Wallensteen, Quality Peace: Peacebuilding, Victory, and World Order (Oxford: Oxford University Press, 2015), 10-28.
} 
unscripted, dispersed agency in everyday politics and social relations, underappreciating the important roles of law and institutions in fostering peace. Using Arendt's thoughts, this article has investigated a middle way between the liberal and critical approaches to peace. What I term her worldly realism, emphasizing both the demands of agonistic action and stable institutions for free politics and their constant balancing, offers a distinctive insight into how to constitute local communities for reducing violence and fostering sustainable peace. By conceiving of the local neither as a completely regulated space nor as a site of sheer indeterminacy, an approach grounded in Arendt's worldly realism favors a balanced form of local agency. Calling for both the establishment of a public realm that can be pluralized as locally common sites for the appearances of actions and opinions and the accommodation of new voices and disruptive actions for change through the integrative process of institutional modifications, it fosters stable institutions but never depletes the agonistic spirit of resistance.

Further investigation of the implications of Arendt's worldly realism is necessary for practical application. For one, how could local communities and sites of agency driven by such a vision of peace be connected, and what form of association might they take? The current world abounds with global problems, such as refugee crises, poverty in the Global South, transnational terrorism, and climate change. Facing these problems, one may find Kantian cosmopolitanism appealing. But Arendt looks for a way to retain extant power bases and connect them in such a manner that they do not "decrease or destroy one other," but that their combined power can make concrete changes. ${ }^{102}$ Her writings suggest that federalismbased on the council system-may serve as a viable solution. Yet Arendt's statements about federalism at times generate more questions than answers. For example, what is the unit of

${ }^{102}$ Arendt, On Revolution, 143. 
federation? Are all units of federation or sites of power equal? Or does Arendt's federal system operate on two separate (or loosely connected) tracks—-domestic and global federations? What is the relationship between the delegates of the lower and those of the higher councils in the federal system she envisions? I have suggested that the integrative feature of Arendt's constitutionalism via augmentation makes gradual changes in the internal arrangements of constitutional states and affects their federal relations. For a complete picture of worldly realism, critical engagements with Arendt's fledging idea of “a world-wide federated structure" ${ }^{103}$ and the scholarship on international federalism and global social movements would be useful. ${ }^{104}$

As Jerome Kohn sensibly points out, most of the interpretive problems with Arendt's works are attributed to "the inherent difficulty of what she sought to understand." 105 One such area of difficulty is the role of institutions in free politics. As noted in this article, Arendt's ambivalence toward institutions is found in many of her works, and this creates interpretive challenges. One can read "the decline of the nation-state" in The Origins of Totalitarianism as Arendt's confirmation of the sheer futility of political institutions in face of the threats posed by the bourgeois projection of imperialist expansion and the racialized identity claim of panmovements. However, Arendt notes in the same book that national institutions act as a barrier against proto-totalitarian forces. ${ }^{106}$ Likewise, one can read On Revolution as Arendt's judgment that the problems relating to "the social question" and the phenomenon of "the rise of the

${ }^{103}$ Arendt, "Karl Jaspers," 93.

${ }^{104}$ See Shinkyu Lee, "The Real Promise of Federalism: A Case Study of Arendt's International Thought," European Journal of Political Theory (Ahead of print, February 2020): 122, at 12-19. https://doi.org/10.1177/1474885120906059.

${ }^{105}$ Jerome Kohn, "Introduction," in Arendt, The Promise of Politics, vii-xxxiii, at xix.

${ }^{106}$ Margaret Canovan, "Is There an Arendtian Case for the Nation-State?" Contemporary Politics 5 (1999): 103-19, at 104. 
social" necessarily foil any attempts to actualize aspirations for public freedom and to care for the world. Yet this interpretation is possible only when we set aside the fourth and fifth chapters of the book, where Arendt shows a strong interest in the institutional housing of freedom, particularly its role in holding at bay natural and quasi-natural forces that threaten to overrun the artificial world of civilization. ${ }^{107}$ One can also accentuate Arendt's accounts of the rise of the social in The Human Condition, using them to justify a radical form of resistance and argue for her strong approval of such. Given the overwhelming threat of neoliberalism accompanied by a mega-state that fuses governmental and corporate modes of power, is it not true that the best political practice we can envision is one that is fugitive, episodic, and momentary? ${ }^{108}$ In this situation, do we not need a radicalized version of action that considers itself the boundary-blurring force par excellence so that it can serve a politics of never-ending, dispersed, and local resistance?

I do not think this vision of politics alone can be the right guide to contemporary peace discourse. Nor do I believe that it is the only possible reading of Arendt's thoughts. The reading I have elaborated here calls attention to both the phenomenological bases of politics as practiced by diverse equals in an institutionally articulated space and the reality of the "dark times" we face. ${ }^{109}$ Arendt urges us to appreciate the remaining traces of authentic politics and maintain the ground of a politically engaged care for the world from which action reliably appears and human civilization is possible. Only that way, she argues, can we drive out totalitarian and quasi-totalitarian forces and come closer to a peace without domination and

\footnotetext{
${ }^{107}$ Waldron, “Arendt's Constitutional Politics," 203-13.

${ }^{108}$ Sheldon Wolin, "Fugitive Democracy," in Fugitive Democracy and Other Essays, ed. Nicholas Xenos (Princeton: Princeton University Press, 2016), 100-14, at 111.

${ }^{109}$ Hannah Arendt, "On Humanity in Dark Times," in Men in Dark Times, 3-32.
} 
enforcement. Of course, worldly realism is not a panacea for all the problems contemporary peace engagements encounter; however, it provides a crucial insight into how local communities should be constituted for peace, thereby offering direction to the politics of resistance and a normative parameter for peace intervention. 


\section{References}

Al-Krenawi, Alean and John R. Graham. "Conflict Resolution through a Traditional Ritual among the Bedouin Arabs of the Negev," Ethnology 38 (1999): 163-74.

Arendt, Hannah. Men in Dark Times (New York: Harcourt, 1968).

Arendt, Hannah. On Violence (New York: Harcourt, 1970).

Arendt, Hannah. The Origins of Totalitarianism (New York: Harcourt Brace, 1973).

Arendt, Hannah. Lectures on Kant's Political Philosophy, ed. Ronald Beiner (Chicago: The University of Chicago Press, 1982).

Arendt, Hannah. The Human Condition (Chicago: The University of Chicago Press, 1998).

Arendt, Hannah. "Philosophy and Politics," Social Research 71 (2004): 427-54.

Arendt, Hannah. The Promise of Politics, ed. Jerome Kohn (New York: Schocken Books, 2005).

Arendt, Hannah. On Revolution (New York: Penguin Books, 2006),

Arendt, Hannah. Between Past and Future: Eight Exercises in Political Thought (New York: Penguin Books, 2006).

Arendt, Hannah. “The Great Tradition: II. Ruling and Being Ruled,” Social Research 74 (2007): 941-54.

Arendt, Hannah. The Jewish Writings, ed. Jerome Kohn and Ron Feldman (New York: Schocken Books, 2007).

Arendt, Hannah. Reflections on Literature and Culture, ed. Susannah Young-ah Gottlieb (Stanford: Stanford University Press, 2007). 
Bargués-Pedreny, Pol. "Connolly and the Never-Ending Critiques of Liberal Peace: From the Privilege of Difference to Vorarephilia," Cambridge Review of International Affairs 30 (2017): 216-34.

Barbara, Julien. "Rethinking Neo-Liberal State Building: Building Post-Conflict Development States," Development in Practice 18 (2008): 307-18.

Benhabib, Seyla. The Reluctant Modernism of Hannah Arendt (Thousand Oaks, CA: Sage Publication, 1996).

Benhabib, Seyla. Another Cosmopolitanism (Oxford: Oxford University Press, 2008).

Björkdahl, Annika and Kristine Höglund. "Precarious Peacebuilding: Friction in GlobalLocal Encounters," Peacebuilding 1 (2013): 289-99.

Björkdahl, Annika and Johanna Mannergren Selimovic. "A Tale of Three Bridges: Agency and Agonism in Peace Building," Third World Quarterly 37 (2016): 321-35.

Brown, Garrett Wallace. Grounding Cosmopolitanism: From Kant to the Idea of a Cosmopolitan Constitution (Edinburgh: Edinburgh University Press, 2009).

Brown, Garrett Wallace. "The Constitutionalization of What? Global Constitutionalism 1 (2012), 201-28.

Canovan, Margaret. The Political Thought of Hannah Arendt (London: J. M. Dent \& Sons Ltd, 1974).

Canovan, Margaret. Hannah Arendt: A Reinterpretation of Her Political Thought (Cambridge: Cambridge University Press, 1992). 
Canovan, Margaret. "Politics as Culture: Hannah Arendt and the Public Realm," in Hannah Arendt: Critical Essays, ed. Sandra K. Hinchman and Lewis P. Hinchman (Albany: State University of New York Press, 1994), 179-206.

Canovan, Margaret. "Is There an Arendtian Case for the Nation-State?" Contemporary Politics 5 (1999): 103-19.

Campbell, David. National Deconstruction: Violence, Identity, and Justice in Bosnia (Minneapolis: University Minnesota Press, 1998).

Doyle, Michael and Nicholas Sambanis. Making W ar and Building Peace: United Nations Peace Operations (Princeton: Princeton University Press, 2006).

Fawn, Rick and Oliver Richmond. "De Facto States in the Balkans: Shared Governance versus Ethnic Sovereignty in Republika Srpska and Kosovo," Journal of Intervention and Statebuilding 3 (2009): 205-38.

Finlay, Christopher. "Hannah Arendt’s Critique of Violence," Thesis Eleven 97 (2009): 26-45.

Frazer, Elizabeth and Kimberly Hutchings. "On Politics and Violence: Arendt contra Fanon," Contemporary Political Theory 7 (2008): 90-108.

Galtung, Johan. "Violence, Peace, and Peace Research," Journal of Peace Research 6 (1969): 167-91.

Goetze, Catherine and Dejan Guzina. "Peacebuilding, Statebuilding, NationbuildingTurtles All the Way Down?” Civil Wars 10 (2008): 319-47.

Graef, Julian. Practicing Post-Liberal Peacebuilding: Legal Empowerment and Emergent Hybridity in Liberia (New York: Palgrave, 2015). 
Hayden, Patrick. Political Evil in a Global Age: Hannah Arendt and International Theory (London: Routledge, 2009).

Hegel, G.W.F. Elements of the Philosophy of Right (Cambridge: Cambridge University Press, 1991).

Honig, Bonnie. Political Theory and the Displacement of Politics (Ithaca, NY: Cornell University Press, 1993).

Honig, Bonnie. Emergency Politics: Paradox, Law, Democracy (Princeton: Princeton University, 2009).

Howes, Dustin Ells. “The Failure of Pacifism and the Success of Nonviolence," Perspectives on Politics 11 (2013): 427-46.

Hutchings, Kimberly. "Pacifism Is Dirty: Towards an Ethico-Political Defense," Critical Studies on Security 6 (2018): 176-92.

Ikenberry, G. John. “The End of Liberal International Order?” International Affairs 94 (2018): $7-23$.

International Commission on Intervention and State Sovereignty, The Responsibility to Protect (Ottawa: International Development Research Center, 2001).

Jacoby, Tim. "Hegemony, Modernization, and Post-War Reconstruction,” Global Society 21 (2007): 521-37.

Keenan, Alan. "Promises, Promises: The Abyss of Freedom and the Loss of the Political in the Work of Hannah Arendt," Political Theory 22 (1994): 297-322. 
Lederach, John Paul and R. Scott Appleby. "Strategic Peacebuilding: An Overview," in Strategies of Peace: Transforming Conflict in a Violent World, ed. Daniel Philpott and Gerard Powers (Oxford: Oxford University Press, 2010), 19-44.

Lee, Shinkyu. "Freedom, the State, and War: Hegel's Challenge to World Peace,” International Politics 54 (2017): 203-20.

Lee, Shinkyu. "The Lex of the Earth? Arendt's Critique of Roman Law," Journal of International Political Theory (Ahead of print, January 2020): 1-18. https://doi.org/10.1177\%2F1755088219898237.

Lee, Shinkyu. “The Real Promise of Federalism: A Case Study of Arendt's International Thought," European Journal of Political Theory (Ahead of print, February 2020): 1-22. https://doi.org/10.1177/1474885120906059.

Lindahl, Hans. "Give and Take: Arendt and the Nomos of Political Community," Philosophy \& Social Criticism 32 (2006): 881-901.

Mac Ginty, Roger. "Hybrid Peace: The Interaction between Top-Down and Bottom-Up Peace," Security Dialogue 41 (2010): 391-412.

Mac Ginty, Roger. "Hybrid Peace: How Does Hybrid Peace Come About?” in A Liberal Peace? The Problems and Practices of Peacebuilding, ed. Susanna Campbell, David Chandler, and Meera Sabaratnam (London: Zed Books, 2011), 209-25.

Mac Ginty, Roger. "Everyday Peace: Bottom-Up and Local Agency in Conflict-Affected Societies," Security Dialogue 45 (2014): 548-64.

Mac Ginty, Roger. "Where Is the Local? Critical Localism and Peacebuilding," Third World Quarterly 36 (2015): 840-56. 
Mac Ginty, Roger and Oliver Richmond. “The Local Turn in Peace Building: A Critical Agenda for Peace," Third World Quarterly 34 (2013): 763-83.

MacGowan, John. "Must Politics be Violent? Arendt's Utopian Vision,” in Hannah Arendt and the Meaning of Politics, ed. Craig Calhoun and John McGowan (Minneapolis: University of Minnesota Press, 1997), 263-96.

Mandelbaum, Michael. The Ideas that Conquered the World: Peace, Democracy, and Free Markets in the Twenty-First Century (New York: Public Affairs, 2002).

Markell, Patchen. “Arendt's Work: On the Architecture of The Human Condition," College Literature 38 (2011): 15-44.

Mazlish, Bruce. The Idea of Humanity in a Global Era (New York: Palgrave, 2009).

Millar, Gearoid, Jaïr van der Lijn, and Willemijn Verkoren. "Peacebuilding Plans and Local Reconfigurations: Frictions between Imported Processes and Indigenous Practices," International Peacekeeping 20 (2013): 137-43.

Mitchell, Audra. “Peace beyond Process?” Millennium: Journal of International Studies 38 (2010): 641-64.

Moe, Louise Wiuff and Finn Stepputat. "Peacebuilding in an Era of Pragmatism," International Affairs 94 (2018): 293-99.

Nadarajah, Suthaharan and David Rampton. "The Limits of Hybridity and the Crisis of Liberal Peace," Review of International Studies 41 (2014): 49-72.

Nygren, Anja. "Local Knowledge in the Environment-Development Discourse: From Dichotomies to Situated Knowledges," Critique of Anthropology 19 (1999): 267-88. 
Owens, Patricia. Between War and Politics: International Relations and the Thoughts of Hannah Arendt (Oxford: Oxford University Press, 2007).

Owens, Patricia. "Walking Corpses: Arendt on the Limits and Possibilities of Cosmopolitan Politics," in International Relations Theory and Philosophy: Interpretive Dialogues, ed. Cerwyn Moore and Chris Farrands (London: Routledge, 2010), 72-82.

Owens, Patricia. "Human Security and the Rise of the Social," Review of International Studies 38 (2012): 547-67.

Paris, Roland. "Saving Liberal Peacebuilding," Review of International Studies 36 (2010): 337-65.

Paris, Roland. At War's End: Building Peace after Civil Conflict (Cambridge: Cambridge University Press, 2006).

Pugh, Michael. "The Political Economy of Peacebuilding: A Critical Theory Perspective," International Journal of Peace Studies 10 (2005): 23-42.

Randazzo, Elisa. "The Paradoxes of the 'Everyday': Scrutinizing the Local Turn in Peace Building," Third World Quarterly 37 (2016): 1351-70.

Rensmann, Lars. “Grounding Cosmopolitics: Rethinking Crimes against Humanity and Global Political Theory with Arendt and Adorno," in Arendt and Adorno: Political and Philosophical Investigations, ed. Lars Rensmann and Samir Gandesha (Stanford: Stanford University Press, 2012), 129-53.

Richmond, Oliver. "The Problem of Peace: Understanding of the 'Liberal Peace," Conflict, Security \& Development 6 (2006): 291-314.

Richmond, Oliver. "Emancipatory Forms of Human Security and Liberal Peacebuilding," International Journal 62 (2007): 459-78. 
Richmond, Oliver. “A Post-Liberal Peace: Eirenism and the Everyday,” Review of International Studies 35 (2009): 557-80.

Richmond, Oliver. "Resistance and the Post-Liberal Peace," Millennium: Journal of International Studies 38 (2010): 665-92, at 685-89.

Richmond, Oliver. "De-Romanticising the Local, De-Mystifying the International: Hybridity in Timor Leste and the Solomon Islands," Pacific Review 24 (2011): 115-36.

Richmond, Oliver and Audra Mitchell. "Peacebuilding and Critical Forms of Agency: From Resistance to Subsistence," Alternatives: Global, Local, Political 36 (2011): 326-44.

Richmond, Oliver and Audra Mitchell. "Introduction-Towards a Post-Liberal Peace," in Hybrid Forms of Peace: From Everyday Agency to Post-Liberalism, ed. Oliver Richmond and Audra Mitchell (New York: Palgrave, 2012), 1-38.

Robins, Simon. “An Empirical Approach to Post-conflict Legitimacy: Victims' Needs and the Everyday," Journal of Intervention and Statebuilding 7 (2013): 45-64.

Sabaratnam, Meera. "Avatars of Eurocentrism in the Critique of the Liberal Peace," Security Dialogue 44 (2013): 259-78.

Schaap, Andrew. Political Reconciliation (London: Routledge, 2005).

Schwartz, Jonathan Peter. "Political Judgment Confronts Ideology: Hannah Arendt's Contribution," Polity 50 (2018): 485-511.

Tsao, Roy. "Arendt against Athens: Rereading The Human Condition,” Political Theory 30 (2002): 97-123. 
United Nations. “An Agenda for Peace-Preventive Diplomacy, Peacemaking, and Peacekeeping: Report of the Secretary-General,” A/47/277 (June 17, 1992), at https://digitallibrary.un.org/record/1473582?ln=en.

United Nations, "High-Level Panel on Threats, Challenges and Change: Report of the Secretary-General,” A/59/565 (December 2, 2004), at https://digitallibrary.un.org/record/536113? $\ln =$ en.

Villa, Dana. Arendt and Heidegger: The Fate of the Political (Princeton: Princeton University Press, 1996).

Villa, Dana. Politics, Philosophy, Terror: Essays on the Thought of Hannah Arendt (Princeton: Princeton University Press, 1999).

Villa, Dana. Public Freedom (Princeton: Princeton University Press, 2008).

Volk, Christian. "From Nomos to Lex: Hannah Arendt on Law, Politics, and Order," Leiden Journal of International Law 23 (2010): 759-79.

Waldron, Jeremy. "Arendt's Constitutional Politics," in The Cambridge Companion to Hannah Arendt, ed. Dana Villa (Cambridge: Cambridge University Press, 2000), 201-19.

Wallensteen, Peter. Quality Peace: Peacebuilding, Victory, and World Order (Oxford: Oxford University Press, 2015).

Weber, Max. "Science as a Vocation,” in From Max Weber: Essays in Sociology, ed. H. H. Gerth and C. Wright Mills (Oxford: Oxford University Press, 1946), 129-58.

Wenman, Mark. Agonistic Democracy: Constituent Power in an Era of Globalization (Cambridge: Cambridge University Press, 2013). 
Wolff, Jonas and Lisbeth Zimmermann. "Between Banyans and Battle Scenes: Liberal Norms, Contestation, and the Limits of Critique," Review of International Studies 42 (2016): 513-34.

Wolin, Richard. The Politics of Being: The Political Thought of Martin Heidegger (New York: Columbia University Press, 1990).

Wolin, Sheldon. "Fugitive Democracy," in Fugitive Democracy and Other Essays, ed. Nicholas Xenos (Princeton: Princeton University Press, 2016), 100-14.

Zanotti, Laura. "Governmentality, Ontology, Methodology: Re-Thinking Political Agency in the Global World," Alternatives: Global, Local, Political 38 (2013): 288-304. 